RESEARCH ETHICS

\title{
New European guidelines for the use of stored human biological materials in biomedical research
}

\section{Trouet}

J Med Ethics 2004;30:99-103. doi: 10.1136/jme.2003.003467

The increasing possibilities for using tissue for research and development in genetics and biotechnology have made stored human biological materials more important than ever. Using stored human biological materials raises many legal and ethical questions. On an international level however, the use of these materials has not been regulated in a detailed manner so far. The Council of Europe recently declassified the text of the proposal for an instrument on the use of archived human biological materials in biomedical research for public consultation. The purpose of this paper is to comment on this document regarding its primary goal, which is to protect the rights and fundamental freedoms of the individual whose biological materials could be included in a research project. The guidelines offer good basic protection for sources of identifiable human biological materials but, surprisingly, offer no protection to sources of anonymous or anonymised materials.

Correspondence to: C Trovet, Kapucijnenvoer 35, 3000 Leuven, Belgium; Caroline.Trovet@med. kuleuven.ac.be

Received 2 February 2003 Revised 9 May 2003 Accepted 2 June 2003

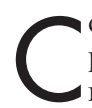
ells and tissues which are retrieved from patients or research subjects in a specific medical context (for example, diagnosis, treatment, or autopsy) are often stored and later used for different purposes such as biomedical research. The increasing possibilities for using tissues for scientific purposes (because of improved analysis techniques which allow more precise analyses of smaller amounts of materials $\left.{ }^{1}\right)$ and the developments in genetics and biotechnology have made stored human biological materials more important than ever. Until recently, doctors did not request consent from or inform patients regarding the further use of biological materials. The changing patient-doctor relationship, the development of patients' rights, public scandals concerning the use of biological materials without the patient's knowledge, ${ }^{2}$ and the expanding transborder flow of materials have increased the need for international regulation in this field.

In October 2002, the Council of Europe declassified the text of the proposal for an instrument on the use of archived human biological materials in biomedical research and its explanatory report for public consultation. ${ }^{3}$ The drafting of this proposal was initiated at the CDBI (Comité Directeur de Bioéthique) plenary held in December 2000 after several delegations had remarked that there was an urgent need for guidance on research on biological materials and personal data. The CDBI appointed two rapporteurs for the preparation of a report which led to this proposal for an instrument. The proposal builds on the principles embodied in the Convention on Human Rights and Biomedicine and in its (draft) Protocol on Biomedical Research, with a view to protecting human rights and dignity in relation to research on human biological materials. The draft guidelines on the research use of human biological materials could not have come at a better time. Unfortunately however, the protection offered in the draft guidelines is limited to sources of identifiable materials. Sources of anonymous or anonymised ${ }^{4}$ samples do not have any bearing on the use of their cells or tissues. We will comment on the guidelines in light of their primary goal, which is to protect the rights and fundamental freedoms of those whose biological materials could be included in a research project, while indicating some shortcomings and criticising the reasoning behind them.

\section{HUMAN BIOLOGICAL MATERIAL}

Article 2 of the draft instrument describes human biological material as material of human origin whether identified, identifiable, or anonymised. ${ }^{5}$ A clear definition of human biological material itself is missing and the definition is not very specific as to the boundaries of what can be considered "materials of human origin". According to Article 3.2, the instrument will not apply to research on unlinked anonymised human cell lines or stem cell lines. ${ }^{6}$ From this provision, we can infer that cell lines fall under the definition of human biological material. The proposal does however not specify to what extent processed human biological materials in general still fall under the definition of human biological material. ${ }^{7}$ This might be important in light of Article 8 of the instrument which prohibits financial gain for human biological material as such. More explanation on this subject in the definition of human biological material or in the explanatory report would be useful.

The draft instrument applies to research based on archived human biological materials. Where this research also entails the use of personal data, the provisions apply to that data (Article 3.1. ii). The research use of personal data as such, however, is not covered by the instrument.

\section{NO CONSENT FOR THE USE OF ANONYMOUS/ANONYMISED CELLS AND TISSUES}

The main concern raised by the instrument is that it permits researchers to use human biological materials without consent as long as 
the tissues are irreversibly anonymised. While this could serve as a satisfactory transitory solution for using collections of tissues that existed before the guidelines were introduced, this is a dangerous starting point for future guidelines. Although it is not possible for certain research projects to work with anonymised tissues, ${ }^{8}$ researchers might sometimes be encouraged to deliberately anonymise samples at a time when it is still possible to request consent. Is it justified to deliberately anonymise biological materials in order to escape from the consent requirement at a time when it is still possible to request consent? ${ }^{9}$

Article 14 indeed stipulates that research on human biological materials and personal data shall only be undertaken if this is done in conformity with appropriate information and consent procedures. Research with human biological material and personal data is research with identified or identifiable human biological material. This provision reflects the principle prescribed in Article 22 of the Convention on Human Rights and Biomedicine which states that "when in the course of an intervention any part of a human body is removed, it may be stored and used for a purpose other than that for which it was removed, only if this is done in conformity with appropriate information and consent procedures." Article 14 however is limited to the research use of identifiable biological materials. For research with anonymised materials, the verification of the anonymisation process by the competent body is sufficient ${ }^{10}$ : no information for or consent from the source is needed.

The exclusion of anonymised material from the informed consent requirement is contestable. Applying the logic from data regulation, where using anonymised data can be done without the consent of the individual concerned, to regulation of the use of human biological materials is erroneous. ${ }^{11}$ Human biological materials cannot be assimilated to data. Human biological materials are more than information; even anonymised they are not neutral to the person from whom they derive. The source can be opposed to certain uses of his (anonymised) cells or tissues for fear of stigmatisation of the group to which he belongs, he might want to exclude them from certain uses if this goes against his personal convictions (whether religious, spiritual, or emotional). A source might for example be opposed to the commercial use of his cells or tissues $^{12}$ or to their use for genetic research. Others would like to exclude certain specific kinds of research such as research on the links between race and crime or between gender and intelligence. ${ }^{13}$ The research use of "sensitive" tissues might also raise objections, even if they were to be used in an anonymous way (for example fetal tissue). Understanding why certain sources refuse the research use of their tissues or cells is as important as understanding why others prefer their tissues be used for research. ${ }^{14}$

Even when sources do not object to the research use of their materials, they would like to be informed about what will happen to their tissues. The explanatory report to the instrument appropriately mentions public scandals concerning the use of human biological materials without the knowledge of the subjects of the research (we are reminded of the Alder Hey scandal, or of the use of Guthrie cards for research which was discovered by the public after the Enschede disaster). Patients want to have confidence in their doctors and this trust is violated when they discover that their biological materials are stored and used for other purposes without their knowledge. If the Council of Europe acknowledges the importance of this confidential relationship, why does it exclude anonymised materials in principle from protection offered by this instrument?

\section{INFRINGEMENT ON THE RIGHT TO PRIVATE LIFE}

The limitation of the informed consent requirement to identifiable materials seems to be contrary to Article 22 of the Convention on Human Rights and Biomedicine ${ }^{15}$ and to Article 8 of the ECHR which protects the right to respect for private life. Although Article 6 of the draft instrument reaffirms the principle of the right to respect for private life introduced in Article 8 with respect to the research use of human biological materials, it limits its protection to the research use of identifiable biological materials (because research is defined as research with human biological materials and personal data). ${ }^{16}$ The limitation of the protection for the use of identifiable materials is odd for a human rights document referring expressly to the right to respect for private life, because research with anonymised biological materials can also infringe on the right to respect for private life.

It is difficult to determine exactly what "private life" means; no generally accepted definition of this concept exists. The meaning of the right to private life originally was limited to the right to intimacy, the right to a private sphere in which the authorities could not enter. For several years now, another aspect of the right to private life has entered the scene in the case law of the European Court of Human Rights and the former European Commission of Human Rights, which is the right to display to the outside world the lifestyle one has chosen for oneself. The accent then lies on the right to private life as a freedom to make fundamental decisions over one's life. ${ }^{17}$

Thus far, the European Court of Human Rights has not explicitly recognised the right to self determination. The case law of the Court however seems to point in the direction of recognition of a right to self determination and of self realisation. The Court stated in the case PG and JH/UK: "Article 8 also protects a right to identity and personal development, and the right to establish and develop relationships with other human beings and the outside world (authors' italics)" ${ }^{18}$ Recently the Court judged in the Pretty case that: "Though no previous case has established as such any right to self-determination as being contained in Article 8 of the Convention, the Court considers that the notion of personal autonomy is an important principle underlying the interpretation of its guarantees". ${ }^{19}$

New rights can be deduced from the right to private life when social changes make this necessary. ${ }^{20}$ The concept of private life has broadened so as to protect an entire range of elements and manifestations of the personality. Not only are the personal identity of the individual and personal data protected, but also the physical integrity and the choice of the destination of one's remains. ${ }^{21}$ Although the European Convention itself does not explicitly refer to the concept of personality, the protective system organised by the Convention is aimed at protecting important aspects of the personality. ${ }^{22}$ In the case of the destination of human remains, the European Commission on Human Rights stated that: "whilst those arrangements are made for a time after life has come to an end, this does not mean that no issue concerning such arrangements may arise under Article 8, since persons may feel the need to express their personality by the way they arrange how they are buried". ${ }^{23}$ Human biological materials still have a (biological and immaterial) link with the person they derive from, even if they are anonymous. Paraphrasing the decision of the Commission, the individual therefore has (the) "need to express his personality by the way he arranges how his biological remains are used".

The determination of the use of human biological materials can, because of changing social, technical, and economic conditions, be considered to fall under the right to private life 
because of the biological and immaterial link between the human biological materials and the person. Even if cells and tissues are anonymised (the right to private life is more than simply data protection ${ }^{24}$ ), the control over these tissues comes under the individual freedom and self development of the individual. ${ }^{25}$ The "personal" value attributed to cells and tissues often is a subjective question, which makes the evaluation of the question whether cells and tissues fall under the protection of the right to private life both difficult and easy. The evaluation of this question by the patient can (will) be very different from that by a researcher. Not everyone experiences privacy in the same way. This should not however be a problem. On the contrary, whatever belongs to the sphere of freedom should not be predetermined by the law. ${ }^{26}$ Self determination by definition signifies using subjective standards.

Some European countries have enacted regulation taking into account this interpretation of the right to private life. Legislation in the Netherlands, ${ }^{27}$ in Iceland, ${ }^{28}$ and proposals for regulation in France $^{29}$ (and Belgium ${ }^{30}$ ) offer the source a say in the destination of his biological materials, even when they are anonymised.

\section{RISK APPROACH}

The draft instrument only protects the informational privacy of the source. The reason for this limited protection lies with the risk approach employed by the rapporteurs. ${ }^{31}$ In regulation on research with human subjects, the benefit-risk analysis is very important. Human subjects can only undergo research interventions when the benefit:risk ratio is proportional. These research interventions imply interference with the physical integrity of the research subject. In the case of research with stored human biological materials, there is no interference with the physical integrity of the source. The classical risk approach used in regulation of research with human subjects is not appropriate for research on human biological materials, where there is, by definition, no physical risk to the source. The only "risk" for the source consists in the disclosure of personal information gained through the research. For anonymised materials this risk is non-existent. A risk evaluation however, is not the sole element to take into consideration. The right to privacy implies the right of the source to have a voice in the use that will be made of his stored cells and tissues. Offering such a voice not only acknowledges the source as an individual, it also increases the confidence in the patient-physician relationship. Even if materials are used in an anonymised way, sources want to be able to decide on that use. Reducing the protection offered to sources of personal data that can be retrieved from tissues is observing the problem from a limited point of view that is satisfactory to researchers but that is not promoting public confidence. Until recently, the patient-doctor relationship was characterised to a certain degree by paternalism; now a more equable relationship is promoted. The recognition of patients' rights plays an important role in this changing relationship which "promotes equalisation" and where trust is allotted a more important role. It is therefore also important to recognise patients' rights in the context of the research use of tissues. The explanatory report acknowledges in principle the importance of the personal integrity of the source, ${ }^{32}$ but no sign of it can be found in the provisions of the instrument themselves. The proposal for an instrument seems to have been written more from a researcher's perspective $^{33}$ than from a human rights perspective.

\section{FREEDOM OF SCIENTIFIC RESEARCH}

Physicians, researchers, and industry fear that sources might receive a greater say in what can be done with their tissues, which could make access to such tissues by researchers practically and/or financially more difficult, and so they stress the freedom of scientific research. Dropping the consent requirement for using anonymised materials would meet some of the researcher's wishes. Such an absolute interpretation of the freedom of scientific research however, would mean that the freedom of scientific research is above other fundamental rights. ${ }^{34}$ The interest of scientific research as invoked in debates on biomedical issues is much broader than just the freedom of scientific research. It is not just a freedom, a request to abstain directed to the authorities, but above all a claim, a right based upon which positive demands are formulated-for example with regard to the use of human biological materials. This situation is comparable with the problem of new information techniques where legal questions are problematic because one expects, based on non-legal motives, that the law in that domain should act in an uncommon and deviant manner. ${ }^{35}$

Freedom of scientific research should be interpreted correctly. It is not so broad as to counter any possible hampering of research. Freedom of research does not imply a (legal or moral) obligation for patients or research subjects to have their tissues used for research. Nor does it permit private interests to take on the form of public interest in order to override individual rights. ${ }^{36}$ Arguments invoked by researchers are mainly of a practical nature. Practical arguments however, do not constitute a valid argument where the protection of a right is concerned. Of course, practical arguments will play a role in the practical implementation of the basic rule (for example, in the use of anonymised tissues one might prefer an opting out system instead of express consent), but they do not weigh on a principal level.

\section{IMPLEMENTATION OF THE CONSENT REQUIREMENT FOR USE OF IDENTIFIABLE CELLS AND TISSUES}

Individuals whose biological materials and personal data may be used in a research project shall be provided with information in a comprehensible form, either in a general format such as a hospital leaflet or in a specific format such as an information and consent form (explanatory report No 59). Article 15.1 enumerates the contents of this general information (that is, the potential of the materials to be stored for research purposes, the right to give or withhold consent to storage and research uses, the right to express specific requests regarding consent procedures for future research use). When a specific research project is envisaged, further relevant information may include the right to give or withhold consent for the project, the right to withdraw consent at any time, any arrangements for disposal of the materials and erasure or rendering the materials or data anonymous, any foreseeable commercial uses of the materials and data, including the research results etc (Article 15.2). In the case of informing the source of the use of biological materials for a specific research project, the instrument enumerates elements that may be included in the information. Some of these elements seem nevertheless essential and should be included in the information compulsorily.

Article 16 stipulates that human biological materials and personal data shall only be stored for research purposes if the individual has not objected. Whether consent to the research project is explicit or implicit shall be determined by the risk to intrusion of private life and any previously expressed specific requests of the individual. The explanatory report (No 61) explains how this consent requirement should function in practice. Consent should be requested whenever possible at the time of collection of the biological materials and personal data, when it is foreseen that the materials will be used for research purposes, or when they are to be included in collections of human biological material that may be used for 
research. Consent forms should be developed that provide for a layered consent ${ }^{37}$ (different options are given to the source to help them understand clearly the nature of the decision they are about to make) which also makes it possible to request consent for future unknown research without resulting in an unconditional blanket consent. Sources can indicate their specific requests regarding consent procedures for future research use (for example, the request to be contacted again if a specific research project is known).

When no consent has been obtained before the research project is envisaged, reasonable efforts should be made to recontact the individual. The explanatory report however, goes further than the text of the instrument itself by arguing that if recontacting the individual is not possible with reasonable efforts, the competent body may authorise the research, provided the risk of intrusion to the private life of the individual is acceptable in relation to the importance of the study. Article 16 only addresses the choice between explicit or implicit consent, not about an exemption to the consent requirement. If one chooses to grant the competent body this responsibility, this should be regulated in the text of the instrument itself.

\section{THE ROLE OF ETHICS COMMITTEES}

Research shall only be undertaken if the research project has been approved by the competent body in conformity with the law, after independent examination of its scientific merit and ethical acceptability (Article 10). Arrangements shall be in place to allow review procedures to be adapted to the particular nature of the research and the ability to identify the human biological materials and data. In the case of anonymised research, anonymity shall be confirmed by a review procedure. An important role is assigned to the competent body; in the case of anonymised materials the protection of the source is completely determined by this body. One should be careful not to relinquish too many responsibilities to the competent bodies, unless the different parties concerned are represented in those bodies and training on this specific subject is provided..$^{38}$

\section{FINANCIAL GAIN}

Although Article 8 stipulates that human biological materials and personal data within the scope of the instrument that are used in research shall not, as such, give rise to financial gain, the explanatory report mainly addresses the financial gain for the source only. It refers to unusually large payments or rewards that might influence decisions on the risks that participants are willing to undertake, and could influence the behaviour of researchers with regard to such risks. Article 8 elaborates on Article 21 of the Convention on Human Rights and Biomedicine. ${ }^{39}$ The Explanatory Report to the Convention (No 132) stresses that under this provision, biological materials should not be bought or sold or give rise to financial gain for the individual from whom they are removed, or for a third party. It might therefore be important to indicate in the explanatory report to the instrument that the prohibition of financial gain also applies to third parties.

The rapporteurs of the instrument will seek the views of the interested parties during the consultation period as to whether remuneration would be permissible/advisable in the case of the creation of a profitable cell line from one individual. Again this gives the impression that the prohibition of financial gain only applies to the source of the material. Financial gain is already made on cell lines, mainly for industry. Is this prohibited, or are cell lines not considered to be "human biological materials" as such?

Finally, the draft instrument stipulates that the competent body must be satisfied that no undue influence, including financial gain, will be exerted on individuals to consent to the use of their biological materials or personal data in research (Article 13). The intention behind this provision is understandable, but is it not incongruous that there is a specific provision excluding undue influence to require sources to consent, when for anonymised materials there is not even a consent requirement?

\section{TRANSITION PERIOD}

When it is not reasonably feasible to fully comply with the provisions of this instrument for the use of collections of human biological materials and personal data made before the instrument came into force, research may only take place if certain conditions are met. Those conditions are fairly general and vague (materials shall not have been collected "unethically"; the research will not have "personal implications" for the individual). They do not offer clear guidance for deciding whether or not the research can take place (for example: does genetic research have "personal implications"?). Leaving their interpretation up to practical guidelines might signify limitation of the protection offered to sources.

\section{CONCLUSION}

The texts proposed by the rapporteurs and the Secretariat set very good basic standards for the protection of sources of identifiable human biological materials-particularly important is the principle of requesting consent if possible at the time of collection of the materials, and the introduction of a layered consent, both for researchers and sources. Other essential rules concern guidelines for information to be given to the ethics committee and sources, the right to withdraw consent, and the rule concerning new findings.

The proposal for an instrument and its explanatory report are important and necessary texts, but they are rather incomplete concerning the protection of sources of anonymous and anonymised materials. Adding some additional rules for the protection of sources in the case of research use of anonymous/anonymised materials would bring the proposal more in line with both the ECHR and the Convention on Human Rights and biomedicine itself.

\section{REFERENCES}

1 Jonsson L, Landegren U. Storing and Using Bio Banks for Research. In: Hansson MG, ed. The Use of Human Bio Banks. Ethical, Social, Economical and Legal Aspects. Uppsala: Universitetstryckeriet, 2001:4.

2 For example the Alder Hey scandal.

3 Steering Committee on Bioethics. Proposal for an instrument on the use of archived human biological materials in biomedical research, 14 October 2002, http://www.coe.int.

4 Anonymous materials: for these tissue samples no identifiable personal information was collected or when it was collected, it was not maintained. Anonymised materials: for these tissues identifiers or codes linking the tissues to personal information were removed.

5 The definitions in the instrument referring to the ability to identify the biological materials are complex and one could question their relevance for the subject treated. The distinction which is made between coded and linked anonymised materials does not come back in the instrument. In both cases, the human biological materials are identifiable (whether they can be linked back by the researcher or by a third party). "Unlinked anonymised" materials are the only actual anonymous materials. Moreover, nothing is addressed with regard to anonymous materials.

6 The reason for this exclusion is not clear, no explanation is offered in the Explanatory Report. It is strange that this specific exclusion for cell lines should be mentioned if the Explanatory Report is correct in saying that the instrument does not apply to unlinked anonymised materials in general.

7 See also Gassner UM. Tissue engineering in Normendschungel. Medizinrecht 2001; 19:553-61

8 Irreversible anonymity can cause problems both for the research and the donor. Anonymity for example eliminates any possibility of obtaining further information about the source and makes it impossible to provide any information to the source. See Royal College of Pathologists. Transitional guidelines to facilitate changes in procedures for handling "surplus" and archival material from human biological samples, 2001.

9 Wright Clayton E. Prospective uses of DNA samples for research. In: Knoppers BM, ed. Human DNA: law and policy. International and
comparative perspectives. The Hague: Kluwer Law International, 1997:294; 
American College of Medical Genetics. Statement on the storage and use of genetic materials. Am J Hum Genet 1995;57:1499-500.

10 Article 10 stipulates that in the case of unlinked anonymised research, anonymity shall be confirmed by a review procedure. Research projects with anonymised human biological materials are evaluated by the competent body in order to know whether human biological materials and related data are indeed unlinked anonymised.

11 See for more information on different regulation models for the research use of human biological materials Trouet C, Sprumont D. Bio Banks: Investing in regulation. In: Ziemele I, ed. Baltic Yearbook of International Law. The Hague: Kluwer Law International, 2002;2:11-19.

12 See for example Boel E. Human gene- and tissue banks as tools in pharmaceutical discovery. In: Sorsa M, Eyfjörö J, eds. Human Bio Banksethical and social issues. Copenhagen: Nordic Committee on Bioethics, 1997:107: "but the public opinion has never really got to terms with the thought that human material, from living or deceased individuals, should be exploited by the pharmaceutical industry for neither research nor production purposes". Also see Perley SN. From control over one's body to control over one's body parts. New York: University Law Review, 1992;13:345.

13 Clayton EW. Prospective uses of DNA samples for research. In: Knoppers BM, ed. Human DNA: law and policy. International and comparative perspectives. The Hague: Kluwer Law International, 1997:298.

14 Lawrence SC. Beyond the grave-the use and meaning of human body parts: a historical introduction. In: Weir RF, eds. Stored tissue samples. Ethical, legal and public policy implications. lowa City: University of lowa Press, 1998:113.

15 Article 22 deals with any part of a human body, it is not limited to identifiable materials (explanatory report to the Convention, no 135).

16 "Parties to the instrument shall protect the dignity and identity of all human beings and guarantee everyone, without discrimination, respect for their right to private life and other rights and fundamental freedoms with respect to any research governed by the instrument" (Article 1). This protection is limited to the extent that Article 2 of the instrument defines research as "research with human biological materials and personal data for health purposes or for scientific research linked to health purposes". This means that research with anonymous or anonymised materials is not covered by Article 1 (see also Article 5).

17 See Warbrick C. The structure of Article 8. European Human Rights Law Review 1998:33.

18 ECHR, PG, JH/UK 25 September 2001, http://hudoc.echr.coe.int/, p 15, $\S 56$.

19 ECHR, Pretty/UK 29 April 2002, http://hudoc.echr.coe.int/.

20 Loucaides LG. Personality and privacy under the European Convention on Human Rights. In: The British Yearbook of International Law 1990. Oxford: Oxford University Press, 1991:178.

21 Harris DJ, O'Boyle M, Warbrick C. Law of the European Convention on Human Rights. London: Butterworths, 1995:306.

22 Loucaides LG. Personality and privacy under the European Convention on Human Rights. In: The British Yearbook of International Law 1990. Oxford: Oxford University Press, 1991:176.

23 ECommHR, 10 March 1981, X/Germany, 874/79, DR, vol 24, 137.
24 Also see Annas GJ. Privacy rules for DNA databanks. JAMA 1993;270:2347.

25 See for example Daniels LB. Commercialization of human tissues: has biotechnology created the need for an expanded scope of informed consent? California Western School of Law 1990:210; Labrusse-Riou C, Baudouin J-L. Produire l'homme: de quel droit? Paris: Presses Universitaires de France, 1997:196.

26 De Hert P. Artikel 8 EVRM en het Belgisch recht. De bescherming van privacy, gezin, woonst en communicatie. Gent: Mys\&Breesch, 1998:75-6.

27 Article 1653w of the Law on the medical treatment contract.

28 Act on Bio Banks, 2000; Winickoff DE. Biosamples, Genomics and human rights: context and content of Iceland's biobanks act. Journal of Bio Law and Business 2000;4:11-17

29 Office Parlementaire d'évaluation des choix scientifiques et technologiques. Rapport sur l'application de la loi no 94-654 du 29 juillet, 1994:34; Conseil d'Etat. Les lois de bioéthique: cinq ans après. Paris: La Documentation française, 1999:100

30 See the bill proposed to implement the EU Directive on the legal protection of biotechnological inventions: Chamber, 2001-2002, no 1886-001.

31 Article 6: "...shall not involve risks to the private life of individuals or a group of individuals disproportionate to its potential benefit" and explanatory report no 32: "research on archived human biological materials may not carry great risks for individual research subjects if sufficient anonymisation has been carried out"

32 For example explanatory report no 60: "it acknowledges the fact that the motivation for allowing the use of one's biological materials and personal data in biomedical research might be out of solidarity, and information on foreseen commercial uses of their contribution to the research may be important to them in taking their decision". These aspects also apply to anonymised materials.

33 Inspiration for this proposal has clearly been found in the guidelines of the Medical Research Council (UK) Human tissue and biological samples for use in research, 2001. Should guidelines drafted by a professional research organisation determine the protection to be offered to sources of tissues on a European (human rights) level?

34 Hermitte M-A. Le séquençage du génome humain: liberté de la recherche et démarche démocratique. In: $\mathrm{F}$ Furkel $\mathrm{F}$, Jung $\mathrm{H}$, eds. Bioéthique et droits de I'homme-Bioethik und Menschenrechte. Köln: Carl Heymanns Verlag KG, 1993:50.

35 Gutwirth S. Waarheidsaanspraken in recht en wetenschap. Antwerp: Maklu, 1993:23.

36 Leenen HJJ. Handboek gezondheidsrecht, I, Rechten van mensen in de gezondheidszorg. Diegem: Bohn Stfleu Van Loghum, 2000:36.

37 Wertz DC. Archived specimens: a platform for discussion. Community Genet 1999:2:51-60

38 See also Council of Europe. Ethical review of biomedical research in Europe: suggestions for best national practices. Strasbourg, 23 June 1998.

39 See also Knoppers BM. Biotechnology. Sovereignty and sharing. In: Caulfield TA, Williams-Jones B, eds. The commercialization of genetic research. Ethical, legal and policy issues. New York: Kluwer Academic/ Plenum, 1999:1-12. 